International Journal of Social Sciences and Humanities
Available online at http://sciencescholar.us/journal/index.php/ijssh
Vol. 3 No. 2, August 2019, pages: $187 \sim 196$
e-ISSN: 2550-7001, p-ISSN: 2550-701X
https://doi.org/10.29332/ijssh.v3n2.313

\title{
Fraud Factors of Financial Statements on Construction Industry in Indonesia Stock Exchange
}

\author{
$\underset{\text { Crosidfor undrates }}{\text { Cross }}$ \\ Yudha Pramana a ${ }^{\text {, Herkulanus Bambang Suprasto }}{ }^{\mathrm{b}}$, I Gusti Ayu Made Dwija Putri ${ }^{\mathrm{c}}$, I Gusti Ayu \\ Nyoman Budiasih d
}

Article history: Received 09 December 2018, Accepted: 30 April 2019, Published: 16 August 2019

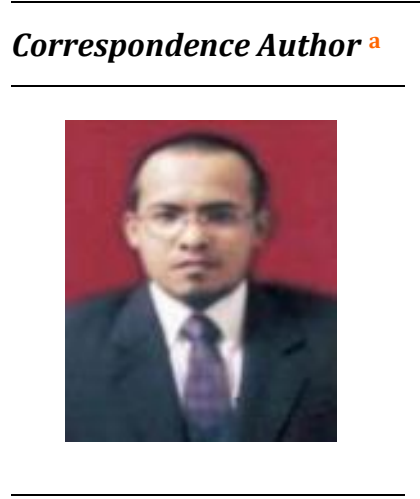

Keywords

audit;

evidence;

financial;

fraud;

triangle;

\begin{abstract}
This research was intended at analyzing the fraud factors of the financial statement using the fraud triangle theory approach. Financial statements manipulation was a fraud form. It was generally difficult to detect. The population was all companies engaged in the construction industry sector. They were listed on the Indonesia Stock Exchange in 2013-2017. The multiple regression is applied for the determination of the sample using purposive sampling techniques and data analysis techniques. The statistical test results showed the opportunity proxied by the audit committee illustrates the effectiveness of the control. It has been negatively affecting the fraudulent financial statements. The rationalization proxied by the auditor's change has a positive effect on the fraudulent financial statements. This study also contributed to the fraud triangle theory. It was provided evidence that elements in the fraud triangle model. They can be used to detect fraudulent financial statements.
\end{abstract}

e-ISSN: 2550-7001, p-ISSN: 2550-701X ๑ Copyright 2019. The Author. SS Journals Published by Universidad Técnica de Manabí. This is an open-access article under the CC BY-SA 4.0 license (https://creativecommons.org/licenses/by-sa/4.0/) All rights reserved.

\section{Contents}

Abstract

1. Introduction.

2. Materials and Methods.......... 190

3. Results and Discussions 190

3.1 Effect of financial targets on financial statement fraud 191

3.2 Effect of number of audit committees on financial statement fraud ......................................................... 191

3.3 Effect of number of independent commissioners on financial statement fraud ......................................... 192

3.4 Effect of auditor change on financial statement fraud 192

a Udayana University, Denpasar, Indonesia

b Udayana University, Denpasar, Indonesia

c Udayana University, Denpasar, Indonesia

d Udayana University, Denpasar, Indonesia 


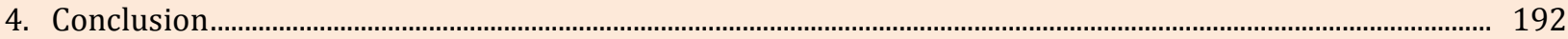

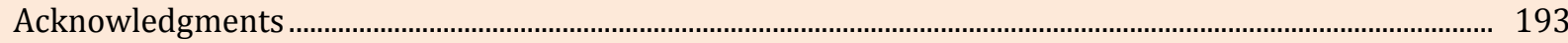

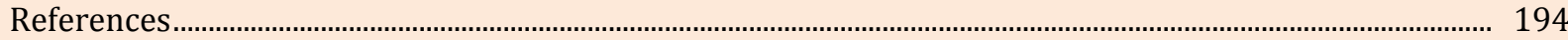

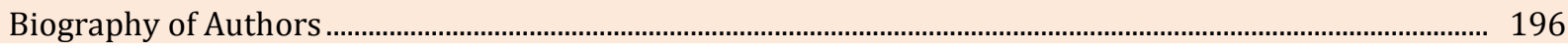

\section{Introduction}

One fraud form in finance is fraudulent financial reporting. It can be done by misstating or ignoring the amount and deliberate disclosure. Therefore, it is to mislead users on financial statements. Fraud can be done in various ways. (a) Manipulation, falsification, and alteration of accounting records or supporting documents. It is the basic form of making financial statements. (b) Misrepresentations or intentional omissions of transactions and other important information. (c) Incorrect application (misapplication) accounting principles for the amount, classification, presentation method, and intentional disclosure.

The phenomenon of financial statement fraud occurs in many countries including Indonesia. They are unlike the Enron scandal have caused investors, workers, and shareholders to suffer a loss of US \$ 74 billion. Waste Management incorrectly reported income of US \$ 1.7 billion. WorldCom has marked up assets of US \$ 11 billion. Lehman Brothers disguised loans as income of US \$ 50 billion (Tuanakotta, 2013).

Financial statement fraud cases generally occur on part of audit failures. Soltani (2014), stated poor quality financial statements has the potential to show deviations. The fraud occurrence on financial statements in accordance with the fraud triangle perspective (Hadi et al., 2018; Sumtaky et al., 2018). It can be caused three main factors namely motives, opportunities, and rationalization. The fraud triangle theory was coined by Cressey (1953). It has been used by practitioners as an approach to detecting a fraud act. Fraud triangle theory was introduced in the professional literature in SAS No. 99. It is called a fraud triangle. Fraud triangle explains the three factors. They are to present in every fraud situation, namely: pressure, opportunity, and rationalization.

Pressure is the incentive/need to commit fraud. It can cover almost anything including lifestyle, economic demands, etc. It is also included financial and non-financial matters. According to SAS No.99, there are four conditions types commonly occur under pressure. It can lead to fraud. They are financial stability, external pressure, personal financial needs, and financial targets.

Opportunity is a situation that opens opportunities to allow for fraud to occur. It usually occurs due to weak internal control of the company, lack of supervision, and authority abuse. It is the most likely element to be minimized through the application of processes, procedures, and early detection efforts against fraud.

Rationalization is the existence of an attitude, character, or set of ethical values. These allow certain parties to commit acts of fraud, or people who are in an environment. It is sufficient pressure. It makes them rationalize fraud. The most widely used rationalization or attitude is borrowing only the stolen assets. Due to their actions are to make the people they love to become happy (Rini et al., 2012). This study examines the fraud factors on the financial statement from the fraud triangle theory model perspective.

\section{Literature Review and Hypothesis}

Fraud occurs in companies can not be separated from three main factors. Martin (2011); Golden et al., (2011); Wells (2018); Cendrowski \& Martin (2007), put forward a fraud triangle. They are motives consisting of pressure, rationalization, and opportunity. The fraud triangle proposed by Donald Cressey (1986), underlies the American Institute Certified Public Accountant (AICPA) to issue Statement on Auditing Standards No. 99 (SAS No. 99) concerning consideration of fraud in a financial statement audit in October 2002. It is to provide solutions to weaknesses in fraud detection procedures in the world (Skousen et al., 2009). International Federation of Accountants (IFAC) publishes International Standards on Auditing (ISA). It illustrates the cheating factor based on fraud triangles theory (Wahyuni \& Budiwitjaksono, 2017).

Pressure can be interpreted as someone feeling pressured or severe conditions when facing difficulties. This can be a motivation for someone to commit fraud. The current research is proxied pressure by the incentives of the board of directors on fraudulent financial statements and financial targets. The incentive variable of the director's board on fraudulent financial statements is based on the analysis of incentive theory and previous research. Incentive theory asserts a careful understanding of internal incentives structure is important in building company activities. The incentives determine the broader scope of how individuals within a company behave (Baker et al., 1988). 
The incentives of the director's board play an important role in the occurrence of fraudulent financial statements. Balsam et al., (2003), suggested a relationship between the compensation of company executives with certain areas. They are unlike company value, revenue management, accounting restatements, and fraud. Therefore, many companies provide large equity incentives to executives. Due to they are considered consistently strengthen the company's internal control, it means minimizing the occurrence of fraud in the company's financial statements. Zhou et al., (2018), released the Chinese capital market by finding that CEOs and financial directors who relatively received low income tended to commit fraud, with or without the pressure of delisting companies in the capital market. Furthermore, Golden et al., (2011), stated a very large bonus or incentive can trigger greed or fear of losing the position of the executives of the company. The following hypothesis was formulated.

\section{$H_{1}$ : Director board incentives have a positive effect on financial statement fraud.}

The second pressure variable is proxied by a financial target. They are a risk due to strong pressure on management in achieving the goals. It is to be achieved the management or directors. It is included in determining bonuses and incentives to be received by employees. Financial targets are closely related to company performance. One of the measurements to assess the profit level of the company is obtained for the business. It is conducted using ROA (Return On Assets) analysis. The higher ROA is targeted by the company, the more susceptible the management is to earn a manipulation. Earnings manipulation is a fraud form. ROA has a positive relationship in financial statement fraud. Putriasih et al., (2016), found the financial targets are a form of company performance measurement on ROA indicators. The results showed that ROA affects the occurrence of financial statement fraud. The hypothesis can be formulated.

\section{$\mathrm{H}_{2}$ : Financial targets have a positive effect on fraudulent financial reporting}

Opportunity is a chance that causes fraudsters to have freedom. It is to carry out their actions caused by weak control, indiscipline, weakness in accessing information, no audit mechanism, and apathy. Opportunity is the cause of people cheating. Fraud individually committed is usually made use for their position on the company. This fraud is not detected (Wells, 2018; Lisa \& Hermanto, 2018; Bire et al., 2019).

Martin (2011), interpreted opportunity as a condition that allows perpetrators to commit fraud. They are unlike the lack of supervision, supervision, regulation, and even law enforcement. Factors driving this opportunity were due to authority abuse, nepotism, lack of oversight mechanisms, weak contract or procurement structures, and minimum sanctions for fraud.

Opportunity in this study was proxied by the number of audit committees. The audit committee is described as the guardian of the financial integrity in an organization. It has played a major role and has contributed greatly to corporate governance since its emergence in the early 1940s (Verschoor \& Wiley, 2008). It was proxied by the number of audit committees and the number of independent commissioners.

The rules on Sarbanes-Oxley Act 2002 stipulate companies listed on the stock exchange must have an audit committee with integrity. It is expected to reduce fraud that occurs within the company. This is in accordance with Verschoor \& Wiley (2008), confirmed the audit committee is the guardian of the company's financial integrity. Hoopes et al., (2017); Ghafran \& Sullivan (2017); and Abbott \& Park (2000), asserted the presence of an audit committee that monitors the company allows the reduction of fraud and financial reporting errors. The hypothesis was proposed.

\section{H3: The number of audit committees has a negative effect on financial statement fraud.}

The second proxy of the opportunity variable is the number of independent directors. A large number of corporate fraud scandals listed on the capital market raises questions about the corporate governance crisis by corporate organs. Unlike the board of commissioners and directors gave rising to the rules on SarbanesOxley Act 2002. It is to strengthen corporate governance by requiring the strengthening of independent directors and commissioners. Uzun et al., (2004), reinforced the urgency of independent commissioners in good and correct corporate governance, where the conclusions of the results of the study state that the composition and structure of the board of directors and supervisory board are very significant with the occurrence of

Pramana, Y., Suprasto, H. B., Putri, I. G. A. M. D., \& Budiasih, I. G. A. N. (2019). Fraud factors of financial statements on construction industry in Indonesia stock exchange. International Journal of Social Sciences and Humanities, 3(2), 187-196. https://doi.org/10.29332/ijssh.v3n2.313 
corporate fraud. Uzun et al., (2004), proved the higher proportion of independent supervisors in a company, the less fraud occurred in a company. The hypothesis was formulated.

\section{$H_{4}:$ The number of independent directors negatively influences on financial statement fraud.}

Association of Certified Fraud Examiners (ACFE) stated the third factor in the occurrence of fraud is a rationalization. It is the attitude shown by the perpetrators of fraud by justifying their actions. It can be interpreted as an act. They looked for reasons justification to people who feel trapped in a bad situation. Perpetrators will find reasons to justify their cheating.

Auditor has a very important role in assessing reasonableness. There is a material misstatement of the company's financial statements either due to errors or fraud. The auditor role is very fundamental to detecting fraud. This condition can cause tension between management and auditor. Therefore, the management can replace the auditor to reduce the possibility of detecting on the financial statement being carried out.

The auditors change on a company can be fraud indication. Due to the old auditor can see all the symptoms of possible committed fraud by management (Permana, 2018). Companies frequently change auditors will give an idea. There is an act of fraud financial statements on the company (Hubens, 2012; Pramanaswari \& Yasa, 2018; Dewi \& Dewi, 2017). The hypothesis was proposed.

$H_{5}$ : Auditors change of independent has a positive influence on financial statement fraud.

\section{Materials and Methods}

Population in this study is a construction sector company listed on the stock exchange in 2013 to 2017. Sample determination used purposive sampling techniques and multiple linear regression analysis techniques are formulated.

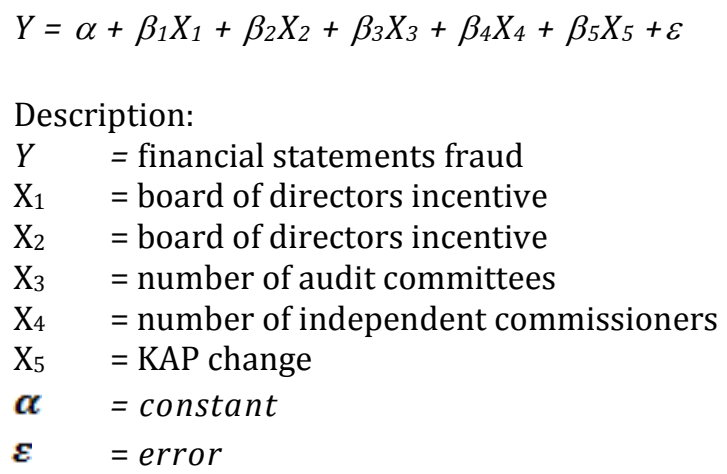

\section{Results and Discussions}

Based on the research test results data is free from the classic assumption problem. The statistical test results on multiple regression techniques are presented in the following Table 1.

Table 1

The results of multiple linear regression statistics tests

\begin{tabular}{|c|c|c|c|c|c|}
\hline \multirow[t]{2}{*}{ Variable } & \multicolumn{2}{|c|}{$\begin{array}{l}\text { Unstandardized } \\
\text { Coefficients }\end{array}$} & \multirow{2}{*}{$\begin{array}{l}\text { Standardized } \\
\text { Coefficients } \\
\text { Beta }\end{array}$} & \multirow[t]{2}{*}{$\mathrm{T}$} & \multirow[t]{2}{*}{ Sig. } \\
\hline & B & Std. Error & & & \\
\hline (Constant) & 2,386 & 1,066 & & 2,239 & 0,027 \\
\hline board of directors & $-0,047$ & $-0,122$ & $-0,031$ & $-0,386$ & 0,700 \\
\hline
\end{tabular}




\begin{tabular}{llllll} 
incentives $\left(\mathrm{X}_{1}\right)$ & & & & & \\
ROA $\left(\mathrm{X}_{2}\right)$ & 2,323 & 3,049 & 0,059 & 0,762 & 0,447 \\
$\begin{array}{l}\text { number of audit } \\
\text { committees }\left(\mathrm{X}_{3}\right)\end{array}$ & -0.719 & 0.304 & $-0,185$ & $-2,367$ & 0,019 \\
$\begin{array}{l}\text { number of independent } \\
\text { commissioners }\left(\mathrm{X}_{4}\right)\end{array}$ & 0.127 & 1.094 & 0,009 & 0,116 & 0,908 \\
KAP change $\left(\mathrm{X}_{5}\right)$ & 0,521 & 0.248 & 0,169 & 2,103 & 0,037 \\
$\mathrm{R}^{2}$ & 0,038 & & & & \\
$\mathrm{~F}$ table & 2,310 & & & & \\
Significance F & 0,047 & & & & \\
\hline
\end{tabular}

Source: SPSS output results, 2018

Based on the statistical tests results in Table 1, the regression equation used in this study can be formulated.

$$
F-S C O R E=2,386-0,047 \mathrm{X} 1+2,323 \mathrm{X} 2-0,719 \mathrm{X} 3+0,127 \mathrm{X} 4+0,521 \mathrm{X} 5
$$

Statistical test results show that the Board of Directors' incentives has a positive effect on financial statement fraud that cannot be proven, so the first hypothesis (H1) cannot be accepted. In this study, the pressure variable which is proxied by the incentives of the board of directors as measured by the number of incentives that the incentives received by the board of directors cannot be proven to have a positive effect on financial statement fraud. The results of this test have not been able to support the fraud triangle theory.

\subsection{Effect of financial targets on financial statement fraud}

ROA is one profitability ratios can measure a company's ability to generate profits from the used assets. This is commonly used to evaluate how proper a company has managed its assets. Every company certainly wants to show that the company has a good ability in managing its assets. The company management generally has a profit target must be achieved every period. The company's success in achieving the profit target will be a positive value for the company in the viewed investors.

A reality occurs is often not in accordance with expectations. It can happen due to the things are outside management's expectations. It is less profitable for the company. It can due to the company not succeed in achieving profit targets. If this happened the management will generally try to find a solution, one of them by manipulating. Therefore, the company still looks consistent in generating profits. They can still achieve predetermined profit targets.

Based on the test results, it is not consistent with Summers \& Sweeney (1998) in Skousen et al., 2009; Putriasih et al., (2016); Nugraheni (2017), showed the statistically financial target variables have a significant influence on financial statement fraud. The failure on testing in this study was due to macroeconomic conditions not in favor towards the construction sector (in general the construction sector experienced sluggishness). It can be seen the return on ROA data. It is a very low and homogeneous research sample.

\subsection{Effect of the number of audit committees on financial statement fraud}

Statistical test results show that the number of audit committees has a negative effect on financial statement fraud, so the third hypothesis (H3) is accepted. The results of this study indicate that the company that has the number of audit committees in accordance with the provisions or more, the lower the value of the F-Score, which means the lower the level of fraudulent financial statements. The condition illustrated from the results of this study is that there are sufficient audit committees, the control will run effectively and the monitoring process will be better. This means that an adequate number of audit committees can produce solutions that can be used to overcome the findings of supervision. This makes the level of financial statement fraud can be minimized.

This study results are consistent with research by Verschoor \& Wiley (2008); Hoopes et al., (2017); Ghafran \& Sullivan (2017); and Abbott \& Park (2000), asserted the presence (meeting) of the audit committee on monitoring the company allows the reduction of fraud and financial reporting errors by the executive.

Pramana, Y., Suprasto, H. B., Putri, I. G. A. M. D., \& Budiasih, I. G. A. N. (2019). Fraud factors of financial statements on construction industry in Indonesia stock exchange. International Journal of Social Sciences and Humanities, 3(2), 187-196. https://doi.org/10.29332/ijssh.v3n2.313 
Based on this description, the study results are also consistent with the statement by Beasley et al., (2000), explained that the high level of corporate fraud is due the lack of intensive audit committee meetings. This study supports the fraud triangle theory whereby the opportunity element that is an element in the fraud triangle theory influences financial statement fraud.

\subsection{Effect of number of independent commissioners on financial statement fraud}

The other proxy used to measure opportunity is the number of independent commissioners. Many corporate fraud scandals are caused the weak corporate governance by corporate organs, for example, the board of commissioners and directors. The efforts to improve governance in the Sarbanes-Oxley Act 2002 issued rules to strengthen corporate governance on requiring the strengthening of independent directors and commissioners. Uzun et al., (2004), reinforced the urgency of independent commissioners in good and correct corporate governance. The composition and structure of the director's board and supervisory board are very significant with the occurrence of corporate fraud.

The research test results cannot prove $\mathrm{H}_{4}$. The number of independent commissioners has a negative effect on financial statement fraud. Therefore, the results are not consistent with the research conducted by Uzun $e t$ al., (2004). Thus, the results of this study do not yet support the opportunity element which is an element in the fraud triangle theory.

\subsection{Effect of auditor change on financial statement fraud}

The statistical test results show KAP change proved to have an effect on financial statement fraud. Thus, $\mathrm{H}_{5}$ was accepted. In this study, KAP change is measured and expressed with a dummy variable. Code one (1) is given to a company if during the observation period the company changes its auditor. In contrast, the zero code (0) is given to companies that do not change auditors during the observation period.

The results showed the company's decision to make auditor changes had a positive effect on financial statements fraud level in the company. This research showed the reasons behind the company change of independent auditors are the possibility to cover up the fraudulent financial statements.

The results are in accordance with the explanation of the auditor's change in the company. It can be an indication of a fraud. Du to the old auditor can see all the possible symptoms of committed fraud by management (Permana, 2018). Companies frequently change auditors will give an idea. There is an act of fraudulent financial statements on the company (Hubens, 2012).

Auditor change is a proxy of rationalization element. It is an element of the fraud triangle theory. Rationalization describes the conditions in which perpetrators of fraud always seek rational justification to justify their actions (Molida \& Chariri, 2011). The results of this study support the fraud triangle theory. There shows rationalization element proxied by KAP change variable can be used to detect financial statement fraud.

\section{Conclusion}

The results of this study indicated that from the five tests on the fraud triangle theory model in detecting financial statement fraud, the two tests were proven. Therefore, this research cannot fully support the fraud triangle theory. The two proven tests are:

1) Opportunity is proxied by the number of audit committees are proven to have a negative influence on financial statement fraud. The test results show the higher number of audit committees, the less likely the occurrence of financial statements fraud.

2) Rationalization is proxied by KAP change is shown by the higher intensity of auditor change on the company, it is indicated the occurrence of financial statements fraud. While the test results cannot be proven are.

3) This research is unable to prove the pressure is proxied by management incentives (directors board) has an effect on financial statement fraud.

4) This research is unable to prove the pressure that is proxied by financial targets has an influence on financial statement fraud. 
5) This research is also not able to prove the opportunity is proxied by the number of independent directors influencing financial statement fraud.

Acknowledgments

The authors would like to thank the editor of IJSSH for their valuable time, support, and advice in completing the present paper.

Pramana, Y., Suprasto, H. B., Putri, I. G. A. M. D., \& Budiasih, I. G. A. N. (2019). Fraud factors of financial statements on construction industry in Indonesia stock exchange. International Journal of Social Sciences and Humanities, 3(2), 187-196. https://doi.org/10.29332/ijssh.v3n2.313 


\section{References}

Abbott, L. J., Park, Y., \& Parker, S. (2000). The effects of audit committee activity and independence on corporate fraud. Managerial Finance, 26(11), 55-68.

Baker, G. P., Jensen, M. C., \& Murphy, K. J. (1988). Compensation and incentives: Practice vs. theory. The journal of Finance, 43(3), 593-616. https://doi.org/10.1111/j.1540-6261.1988.tb04593.x

Balsam, S., Krishnan, J., \& Yang, J. S. (2003). Auditor industry specialization and earnings quality. Auditing: A journal of practice \& Theory, 22(2), 71-97. https://doi.org/10.2308/aud.2003.22.2.71

Beasley, M. S., Carcello, J. V., Hermanson, D. R., \& Lapides, P. D. (2000). Fraudulent financial reporting: Consideration of industry traits and corporate governance mechanisms. Accounting Horizons, 14(4), 441454. https://doi.org/10.2308/acch.2000.14.4.441

Bire, A. R., Sauw, H. M., \& Maria, -. (2019). The effect of financial literacy towards financial inclusion through financial training. International Journal of Social Sciences and Humanities, 3(1), 186-192. https://doi.org/10.29332/ijssh.v3n1.280

Cendrowski, H., Martin, J. P., \& Petro, L. W. (2007). Handbook of fraud deterrence. John Wiley \& Sons.

Cressey, D. R. (1953). Other people's money; a study of the social psychology of embezzlement.

Cressey, D. R. (1986). Why managers commit fraud. Australian \& New Zealand Journal of Criminology, 19(4), 195-209. https://doi.org/10.1177\%2F000486588601900402

Dewi, I. G. A. A. O., \& Dewi, I. G. A. A. P. (2017). Corporate social responsibility, green banking, and going concern on banking company in Indonesia stock exchange. International Journal of Social Sciences and Humanities, 1(3), 118-134. https://doi.org/10.29332/ijssh.v1n3.65

Fahlina Permana, J. (2018). Pengaruh fraud diamond terhadap kecurangan laporan keuangan pada sektor pertambangan yang terdaftar di bursa efek indonesia tahun 2012-2016 (Doctoral dissertation, STIE PERBANAS SURABAYA).

Ghafran, C., \& O'Sullivan, N. (2017). The impact of audit committee expertise on audit quality: Evidence from UK audit fees. The British Accounting Review, 49(6), 578-593. https://doi.org/10.1016/j.bar.2017.09.008

Golden, T. W. (2011). A guide to forensic accounting investigation. John Wiley \& Sons.

Hadi, A., Handajani, L., \& Putra, I. N. N. A. (2018). Financial Disclosure based on Web-ICT Determinants: Its Implications for Local Government Financial Performance in Indonesia. International Research Journal of Management, IT and Social Sciences, 5(1), 72-85.

Hoopes, J. L., Merkley, K. J., Pacelli, J., \& Schroeder, J. H. (2018). Audit personnel salaries and audit quality. Review of Accounting Studies, 23(3), 1096-1136.

Hubens, R. J. P. R. (2012). The Influence of the Financial Crisis on Auditor Changes and Earnings Management. Tilburg University, Available at: http://arno. uvt. nl/show. cgi.

Lisa, O., \& Hermanto, B. (2018). The effect of tax amnesty and taxpayer awareness to taxpayer compliance with financial condition as intervening variable. International Research Journal of Management, IT and Social Sciences, 5(2), 227-236.

Martin, J. A., Hamilton, B. E., Ventura, S. J., Osterman, M. J., \& Mathews, T. J. (2013). Births: final data for 2011.

Molida, R., \& Chariri, A. (2011). Pengaruh financial stability, personal financial need dan ineffective monitoring pada financial statement fraud dalam perspektif fraud triangle (Doctoral dissertation, Universitas Diponegoro).

Nugraheni, A. U., \& Septiarini, D. F. (2017). Pengaruh Equivalent Rate, Profitabilitas, dan Jumlah Kantor Terhadap Dana Pihak Ketiga BPRS di Indonesia (Periode Tahun 2013-2015). Jurnal ekonomi syariah teori dan terapan, 4(11), 875.

Pramanaswari, A. S. I., \& Yasa, G. W. (2018). Graham \& Dodd theory in stock portfolio performance in LQ 45 index at Indonesia stock exchange. International Research Journal of Management, IT and Social Sciences, 5(6), 52-59. https://doi.org/10.21744/irjmis.v5n6.338

Putriasih, K., Herawati, N. T., AK, S., \& Wahyuni, M. A. (2016). Analisis Fraud Diamond Dalam Mendeteksi Financial Statement Fraud: Studi Empiris pada Perusahaan Manufaktur yang Terdaftar di Bursa Efek Indonesia (bei) Tahun 2013-2015. JIMAT (Jurnal Ilmiah Mahasiswa Akuntansi) Undiksha, 6(3).

Rini, V. Y., \& Achmad, T. (2012). ANALISIS PREDIKSI POTENSI RISIKO FRAUDULENT FINANCIAL STATEMENT MELALUI FRAUD SCORE MODEL (Studi Empiris pada Perusahaan Manufaktur y ang Terdaftar di Bursa Efek Indonesia Tahun 2008-2010) (Doctoral dissertation, Fakultas Ekonomika dan Bisnis). 
Skousen, C. J., Smith, K. R., \& Wright, C. J. (2009). Detecting and predicting financial statement fraud: The effectiveness of the fraud triangle and SAS No. 99. In Corporate governance and firm performance (pp. 5381). Emerald Group Publishing Limited. https://doi.org/10.1108/S1569-3732(2009)0000013005

Soltani, B. (2014). The anatomy of corporate fraud: A comparative analysis of high profile American and European corporate scandals. Journal of business ethics, 120(2), 251-274.

Summers, S. L., \& Sweeney, J. T. (1998). Fraudulently misstated financial statements and insider trading: An empirical analysis. Accounting Review, 131-146.

Sumtaky, M., Chandrarin, G., \& Sanusi, A. (2018). Effect of elements of regional financial management towards SKPD regency/city performance and its implication on public service. International Research Journal of Engineering, IT \& Scientific Research, 4(2), 73-86.

Tuanakotta, T. M. (2013). Mendeteksi Manipulasi Laporan Keuangan. Jakarta: Salemba Empat.

Uzun, H., Szewczyk, S. H., \& Varma, R. (2004). Board composition and corporate fraud. Financial Analysts Journal, 60(3), 33-43.

Verschoor, C. C. (2008). Audit committee essentials. Wiley.

Wahyuni, W., \& Budiwitjaksono, G. S. (2017). Fraud triangle sebagai pendeteksi kecurangan laporan keuangan. Jurnal Akuntansi, 21(1), 47-61. http://dx.doi.org/10.24912/ja.v21i1.133

Wells, J. T. (2018). International Fraud Handbook. John Wiley \& Sons.

Zhou, F., Zhang, Z., Yang, J., Su, Y., \& An, Y. (2018). Delisting pressure, executive compensation, and corporate fraud: $\quad$ Evidence from China.Pacific-Basin Finance Journal, 48, 17-34. https://doi.org/10.1016/j.pacfin.2018.01.003

Pramana, Y., Suprasto, H. B., Putri, I. G. A. M. D., \& Budiasih, I. G. A. N. (2019). Fraud factors of financial statements on construction industry in Indonesia stock exchange. International Journal of Social Sciences and Humanities, 3(2), 187-196. https://doi.org/10.29332/ijssh.v3n2.313 


\section{Biography of Authors}

\begin{tabular}{|c|c|}
\hline & $\begin{array}{l}\text { Yudha Pramana, S.E. was born on June 14th, } 1979 \text { in Jakarta. He is a college } \\
\text { student on the master of accounting in the faculty of economics and business, } \\
\text { Universitas Udayana. She lives at Jl. Multi Karya I No. 31-E RT/RW 009/09 Utan } \\
\text { Kayu Utara, East Jakarta. He graduated his bachelor degree in Faculty of } \\
\text { Economics and Business, Prof. DR. Mustopo University, Jakarta in } 2012 \text { and DIII of } \\
\text { taxation, STAN Jakarta in 2000. } \\
\text { Email: yupramana@gmail.com }\end{array}$ \\
\hline & $\begin{array}{l}\text { Dr. Drs. Herkulanus Bambang Suprasto, M.Si., Ak., CA was born on August } 28^{\text {th }} \text {, } \\
\text { 1963, in Denpasar. He is a lecturer in the faculty of economics and business, } \\
\text { Udayana University from } 1990 \text { to present. He lives at Jl. Kusuma Bangsa II, } \\
\text { Denpasar. He graduated his bachelor degree in Accounting, Airlangga University in } \\
\text { 1989. He finished his Master of Financial Accounting at Gajah Mada University in } \\
\text { 2003. He completed his doctorate at Brawijaya University in } 2013 . \\
\text { Email: herculanusbambang2017@gmail.com }\end{array}$ \\
\hline & $\begin{array}{l}\text { Dr. I Gusti Ayu Made Asri Dwija Putri, SE., Msi., CMA is a lecturer in the faculty of } \\
\text { economics and business, Universitas Udayana. He graduated her bachelor degree } \\
\text { in Accounting at Universitas Udayana. He finished her Masters of Accounting at } \\
\text { Gajah Mada University. He completed her doctorate degree at Brawijaya } \\
\text { University. } \\
\text { Email: igamasri@yahoo.com }\end{array}$ \\
\hline s.7. 12 & $\begin{array}{l}\text { Dr. I Gusti Ayu Nyoman Budiasih, S.E., M.Si., CSRS., CSRA was born on January } 15^{\text {th }} \text {, } \\
1969 \text { in Denpasar. She is a lecturer in the faculty of economics and business, } \\
\text { Universitas Udayana. She lives at Jalan Dukuh I No. } 10 \text { Gatsu, East Denpasar. She } \\
\text { graduated her bachelor degree in Accounting, Udayana University. She Finished } \\
\text { her Master of Financial Accounting at Gajah Mada University. She completed her } \\
\text { doctorate degree in Brawijaya University. } \\
\text { Email: iganbudiasih17@gmail.com }\end{array}$ \\
\hline
\end{tabular}

